\title{
Kejahatan Narkotika Pada Masa Pandemi Covid-19 di Kota Kendari
}

\author{
La Ode Muhamad Sulihin ${ }^{1 *}$ \\ ${ }^{1}$ Fakultas Hukum, Universitas Halu Oleo, Indonesia \\ *Korespondensi: Imsulihin@uho.ac.id
}

\begin{tabular}{|c|c|}
\hline Info A & Abstrak \\
\hline $\begin{array}{c}\text { Diterima } 25 \text { Juli } \\
2021 \\
\text { Disetujui } 23 \\
\text { Agustus } 2021 \\
\text { Dipublikasikan } 27 \\
\text { Agustus } 2021\end{array}$ & $\begin{array}{l}\text { Peredaran gelap dan penyalahgunaan narkotika telah menjangkau seluruh } \\
\text { pelosok daerah di Indonesia. Para sindikat menyasar anak dan remaja } \\
\text { sebagai tujuan penyalahgunaan narkotika tersebut walaupun saat ini } \\
\text { penyelahgunaan narkotika telah merebak kesemua strata sosial } \\
\text { masyarakat. Di tengah keresahan bangsa Indonesia karena adanya } \\
\text { wabah Covid-19, kejahatan narkotika juga menjadi perhatian karena } \\
\text { peningkatan jumlah kasus yang signifikan di beberapa daerah. Melalui } \\
\text { tulisan ini, penulis hendak menganalisis fenomena kejahatan peredaran } \\
\text { gelap dan penyalahgunaan narkotika di Kota Kendari pada masa pandemi }\end{array}$ \\
\hline $\begin{array}{r}\text { Keywc } \\
\text { Kejah } \\
\text { Narkotika, } \\
\text { Covic }\end{array}$ & $\begin{array}{l}\text { Covid-19 sehingga dapat memberikan sumbangsih pemikiran kepada } \\
\text { semua pihak yang terkait dalam melakukan upaya penanggulangan } \\
\text { terhadap kejahatan narkotika di kota Kendari. Penelitian ini digolongkan } \\
\text { dalam jenis penelitian deskriptif yang berdasarkan fokus kajiannya } \\
\text { merupakan penelitian normatif-empiris. Pengumpulan data dengan }\end{array}$ \\
\hline $\begin{array}{l}\text { (C) } 2021 \text { The } \\
\text { Author(s): This is } \\
\text { an open-access } \\
\text { article distributed } \\
\text { under the terms of } \\
\text { the Creative } \\
\text { Commons } \\
\text { Attribution } \\
\text { ShareAlike (CC BY- } \\
\text { SA 4.0) } \\
\text { cc) }\end{array}$ & $\begin{array}{l}\text { menggunakan studi kepustakaan. Kasus tindak pidana narkotika yang } \\
\text { terjadi di kota Kendari mengalami peningkatan yang serius selama masa } \\
\text { pandemi Covid-19. Pada tahun } 2019 \text { atau sebelum pandemi Covid-19 } \\
\text { melanda sebanyak } 36 \text { kasus, akan tetapi selama pandemi Covid-19 } \\
\text { melanda, pada tahun } 2020 \text { melonjak hingga } 102 \text { kasus dan pada tahun } \\
2021 \text { sampai dengan bulan Mei telah terjadi kasus tindak pidana narkotika } \\
\text { sebanyak } 64 \text { kasus. Pada masa pandemi Covid-19, berdasarkan } \\
\text { pengawasan DJBC tren modus operandi yang dilakukan para } \\
\text { penyelundup narkotika untuk memasukan narkotika ke Indonesia } \\
\text { mengalami perubahan. Tingginya tingkat peredaran dan penyalahgunaan } \\
\text { narkotika, tidak terlepas dari faktor penyebabnya, yaitu faktor individu, } \\
\text { faktor zat dari narkotika itu sendiri yang dapat mengakibatkan } \\
\text { ketergantungan, dan faktor pergaulan di masyarakat. }\end{array}$ \\
\hline & $\begin{array}{l}\text { Abstract } \\
\text { Illicit trafficking and narcotics abuse has reached all corners of the region } \\
\text { in Indonesia. The syndicates target children and adolescents as the target } \\
\text { of narcotics abuse, although currently narcotics abuse has spread to all } \\
\text { social strata of society. In the midst of the anxiety of the Indonesian people } \\
\text { due to the Covid-19 outbreak, narcotics crime is also a concern due to the } \\
\text { significant increase in the number of cases in several regions. Through this } \\
\text { paper, the author wants to analyze the phenomenon of illicit trafficking and } \\
\text { narcotics abuse in Kendari City during the Covid-19 pandemic so that it } \\
\text { can contribute thoughts to all parties involved in making efforts to } \\
\text { overcome narcotics crime in the city of Kendari. This research is classified } \\
\text { in the type of descriptive research based on the focus of the study is }\end{array}$ \\
\hline
\end{tabular}


normative-empirical research. Collecting data by using literature study.
Narcotics crime cases that occurred in the city of Kendari experienced a
serious increase during the Covid- 19 pandemic. In 2019 or before the
Covid- 19 pandemic hit as many as 36 cases, but during the Covid-19
pandemic, in 2020 it jumped to 102 cases and from 2021 to May there
were 64 cases of narcotics crime. During the Covid-19 pandemic, based
on DJBC's supervision, the modus operandi trend of narcotics smugglers
to import narcotics into Indonesia underwent a change. The high level of
distribution and abuse of narcotics, cannot be separated from the
causative factors, namely individual factors, substance factors from
narcotics itself that can lead to dependence, and socializing in society
factors.

\section{Pendahuluan}

Kejahatan merupakan suatu fenomena yang kompleks di masyarakat, dimana kejahatan dapat dipahami dari berbagai sisi yang berbeda. Tak mudah untuk memahami kejahatan. Sejak berabad-abad yang lalu, usaha untuk memahami kejahatan telah dilakukan oleh para ilmuwan (Santoso \& Zulfa, 2011). Kejahatan atau tindak kriminal merupakan salah satu bentuk dari perilaku menyimpang yang selalu ada dan melekat pada masyarakat. Kejahatan merupakan suatu ancaman terhadap norma sosial dalam masyarakat serta ancaman bagi berlangsungnya ketertiban sosial, sehingga kejahatan merupakan masalah kemanusiaan dan juga masalah sosial (Muladi \& Arief, 2005).

Salah satu kejahatan yang mengancam masyarakat adalah kejahatan narkotika. Kejahatan narkotika merupakan salah satu bentuk kejahatan luar biasa (extraordinary crime) yang bersifat transnasional (transnational crime) dan terorganisir (organized crime) sehingga dalam melakukan kejahatan tersebut dilakukan secara sistematis dengan modus operandi yang tinggi serta teknologi canggih (Krisnawati et al., 2006). Oleh karena itu berdasarkan konvensi internasional, peredaran gelap narkotika dan kejahatan narkotika lainnya (unlawful traffic in drugs and related drug offenses) merupakan salah satu kategori kejahatan internasional dari 28 kategori kejahatan internasional yang ada (Hiariej, 2009).

Semakin maraknya peredaran gelap dan penyalahgunaan narkotika mengakibatkan kekhawatiran yang sangat tinggi bagi masyarakat. Tidak hanya masyarakat yang ada di Indonesia, tetapi juga seluruh masyarakat yang ada di dunia. Peredaran gelap dan penyalahgunaan narkotika telah menjangkau seluruh pelosok daerah di Indonesia. Para sindikat menyasar anak dan remaja sebagai tujuan penyalahgunaan narkotika tersebut. Parahnya lagi kondisi saat ini penyelahgunaan narkotika telah merebak kesemua strata sosial masyarakat (Krisnawati et al., 2006). Tidak terkecuali di Kota Kendari, sebagai salah satu daerah yang tingkat peredaran gelap dan penyalahgunaan narkotika sangat memprihatinkan.

Pada bulan Desember 2019 muncul virus baru yang berasal dari kota Wuhan, Cina yang disebut dengan Coronavirus Disease 2019 atau Covid-19. Penyebaran virus ini sangat cepat hampir di seluruh negara di penjuru dunia termasuk Indonesia. Oleh karena itu, penyebaran Covid-19 telah menjadi pandemi karena seluruh negara terindikasi terdapat warganya yang terpapar virus tersebut. Secara resmi melalui pemerintah disampaikan bahwa Covid-19 muncul di Indonesia untuk pertama kalinya adalah pada 2 Maret 2020. Penyebaran Covid-19 di Indonesia 
membawa pengaruh dan dampak yang sangat besar terhadap kehidupan sosial dan ekonomi di lingkungan masyarakat (Triana \& Fauzi, 2020).

Pada tanggal 11 Maret 2020, melalui Organisasi Kesehatan Dunia atau World Health Organization (WHO) menetapkan wabah virus corona Covid-19 sebagai pandemi. Penetapan tersebut ditandai dengan peningkatan jumlah kasus yang terpapar Covid-19 yang sangat cepat dalam waktu yang singkat serta dengan cepat menyebar ke berbagai negara. Penyebaran Covid-19 menyebabkan angka kematian yang semakin meningkat serta berdampak pada berbagai aspek (Maricar \& Nurfani, 2021). Selain berdampak pada kehidupan sosial dan ekonomi, penyebaran Covid-19 juga membawa dampak pada aspek politik, budaya serta ada kecenderungan meningkatnya kejahatan-kejahatan tertentu di tengah masa pandemi Covid-19 di Indonesia.

Di tengah keresahan bangsa Indonesia saat ini karena adanya wabah Coronavirus Disease 2019 (Covid-19) yang melanda hampir di seluruh dunia, peredaran gelap dan penyalahgunaan narkotika juga menjadi perhatian karena peningkatan jumlah kasus yang signifikan di beberapa daerah di tengah pandemi yang sedang melanda (Adhitya, 2020). Adanya fenomena peningkatan kejahatan narkotika dibeberapa daerah di Indonesia pada masa pandemi Covid-19 menjadi perhatian tersendiri.

Trend kejahatan narkotika dalam masa pandemi Covid-19 tidak mudah disimpulkan bahwa telah terjadi kenaikan atau penurunan. Data kejahatan narkotika pada tingkat nasional tidak selalu mencerminkan data pada tingkat daerah. Jenis kejahatan narkotika dapat saja meningkat di wilayah tertentu, tetapi dapat pula menurun di wilayah lain. Misalnya di Sulawesi Tenggara, berdasarkan data (BPS Provinsi Sulawesi Tenggara, 2021), beberapa daerah seperti Buton, Muna, Kolaka, Konawe Selatan, Bombana, Wakatobi dan Kolaka Utara mengalami peningkatan kasus kejahatan narkotika yang sangat kecil sepanjang tahun 2020 . Sebaliknya, beberapa daerah seperti Konawe dan Baubau mengalami penurunan tingkat kejahatan narkotika pada masa pandemi ini. Hal yang berbeda dengan kota Kendari yang mengalami peningkatan kasus kejahatan narkotika pada masa pandemi ini yang sangat tinggi dimana meningkat hampir 300\%. Tingginya peningkatan kejahatan narkotika di kota Kendari tidak dapat dilepaskan dari kondisi pandemi Covid-19.

Pada masa pandemi Covid-19 di Indonesia, berdasarkan data menunjukan peningkatan yang drastis terhadap angka kriminalitas. Kejahatan yang bayak terjadi pada masa pandemi Covid-19 diantaranya street crime atau kejahatan jalanan yang berupa pencurian dengan kekerasan, pencurian biasa, perdagangan narkotika dan kejahatan cyber (Millah, 2020). Para pelaku kejahatan tersebut, memanfaatkan kondisi bangsa yang tengah berjuang melawan penyebaran Covid19, dimana seluruh aparat pemerintah pusat maupun daerah termasuk TNI dan Polri sedang fokus melakukan upaya penanggulangan penyebaran Covid-19 termasuk berbagai dampak yang ditimbulkan, baik politik, sosial, maupun dampak ekonomi. Oleh karena itu, melalui tulisan ini, penulis hendak menganalisis fenomena kejahatan narkotika di kota Kendari yang terjadi pada masa pandemi Covid-19 ini. Penulis berharap dengan tulisan ini dapat memberikan sumbangsih pemikiran kepada semua pihak yang terkait dalam melakukan upaya penanggulangan terhadap peredaran dan penyalahgunaan narkotika di kota Kendari. 


\section{Metode Penelitian}

Berdasarkan sifatnya, penelitian ini digolongkan dalam jenis penelitian deskriptif yang merupakan suatu bentuk penelitian yang ditujukan untuk mendeskripsikan fenomena-fenomena yang ada. Melalui data deskriptif penulis mengidentifikasi fenomena hukum sebagai fenomena sosial. yang kemudian menghubungkan kedua fenomena tersebut secara timbal balik. Sementara itu berdasarkan fokus kajiannya, penelitian ini merupakan penelitian normatif-empiris yang merupakan jenis penelitian hukum normatif dengan data sekunder yang didukung dan dilengkapi dengan data primer atau data empirik (Irwansyah, 2020).

Pengumpulan data dalam penelitian ini dengan menggunakan studi kepustakaan. Tujuannya adalah untuk menunjukkan jalan pemecahan permasalahan penelitian. Dengan studi kepustakaan maka akan diperoleh konsepkonsep yang bersifat umum yang berkaitan dengan penelitian serta akan diperoleh informasi empirik yang spesifik yang berkaitan dengan penelitian. Penelitian ini menggunakan analisis data deskriptif dengan memaparkan gambaran secara deskriptif mengenai sesuatu variabel tertentu saja (Sunggono, 2011).

\section{Hasil}

Ancaman peredaran gelap maupun penyalahgunaan narkotika semakin meluas di berbagai daerah di Indonesia, tidak terkecuali di kota Kendari. Tidak dapat disangkal bahwa peredaran gelap dan penyalahgunaan narkotika menimbulkan kerugian yang besar setiap tahunnya bagi negara dan masyarakat. Dampak yang ditimbulkan kepada negara meliputi beban anggaran yang harus dikeluarkan untuk membiayai usaha pencegahan dan penanggulangan kejahatan narkotika (dalam arti luas), berkurangnya kewibawaan pemerintah (negara) dimata warganya serta menimbulkan gangguan terhadap ketertiban dan keamanan masyarakat dan bangsa. Sementara dampak untuk masyarakat berupa kerusakan jasmaniah dan rohaniah, hilangnya nyawa, hancurnya ekonomi serta perasaan ketakutan yang mengganggu mereka (Reksodiputro, 2020).

Dalam situasi pandemi Covid-19 yang melanda Indonesia sejak awal Maret 2020 sampai dengan saat ini (kurang lebih telah 1 tahun 4 bulan) tidak membuat peredaran narkotika menjadi berkurang. Para sindikat kejahatan narkotika memanfaatkan momen pandemi Covid-19 untuk mengedarkan narkotika kepada masyarakat. Para sindikat kejahatan narkotika tersebut memanfaatkan kelengahan negara dalam hal ini aparat penegak hukum yang tengah berkonsentrasi membantu pemerintah dalam menangani permasalahan yang ditimbulkan akibat pandemi Covid-19 ini.

Berdasarkan beberapa penelitian yang telah dilakukan sebelumnya terkait kejahatan narkotika pada masa pandemi Covid-19, diantaranya yakni mengenai keterlibatan wanita dalam tindak pidana peredaran narkotika pada masa pandemi Covid-19 di wilayah hukum polda Sumatera Selatan. Dalam penelitian tersebut menunjukan peningkatan kasus peredaran dan penyalahgunaan narkotika selama masa pandemi Covid-19 khususnya pada tahun 2020. Penelitian tersebut menguraikan faktor keterlibatan wanita dalam peredaran narkotika di Sumatera Selatan serta upaya penanggulangannya (Adhitya, 2020). Penelitian lain yang juga membahas kejahatan narkotika pada masa pandemi Covid-19 yakni terkait dengan tantangan dan strategis pengawasan narkotika pada masa pandemi Covid-19. Penelitian ini membahas tentang pengawasan barang kiriman yang melalui kantor 
pos KPPBC TMP A Bandung terkait penyelundupan narkotika pada masa pandemi Covid-19 ini (Muchtar \& Aziz, 2020).

Penelitian-penelitian tersebut, memiliki perbedaan dengan yang penulis lakukan khususnya terkait lokasi dan obyek penelitian. Penelitian ini fokus pada fenomena peredaran dan penyalahgunaan narkotika pada masa pandemi Covid19 di kota Kendari. Sementara pada penelitian di atas, hanya sebatas keterlibatan wanita dalam peredaran narkotika serta pengawasan dalam penyelundupan narkotika. Melalui tulisan ini, dapat menggambarkan fenomena kejahatan narkotika di kota Kendari yang terjadi pada masa pandemi Covid-19 serta faktor penyebabnya secara teoritis sehingga dapat menjadi salah satu rekomendasi dalam upaya penanggulangannya.

Berdasarkan hasil penelitian, kasus tindak pidana narkotika yang terjadi di kota Kendari mengalami peningkatan yang serius selama masa pandemi Covid-19. Berdasarkan data dari Kepolisian Resor Kota Kendari, Satuan Reserse Narkoba menunjukan peningkatan angka kasus tindak pidana narkotika. Berikut adalah data kasus tindak pidana narkotika yang terjadi di kota Kendari.

Tabel 1. Data Kasus Tindak Pidana Narkotika di Kota Kendari

\begin{tabular}{cc}
\hline Tahun & Jumlah Kasus \\
\hline 2019 & 36 \\
2020 & 102 \\
Per Mei 2021 & 64 \\
\hline
\end{tabular}

\section{Sumber: Data Satuan Reserse Narkoba Polresta Kendari}

Berdasarkan data di atas, menunjukan bahwa kasus tindak pidana narkotika yang terjadi di kota Kendari pada tahun 2019 atau sebelum pandemi Covid-19 melanda adalah sebanyak 36 kasus. Dari keseluruhan kasus tersebut, narkotika jenis shabu-shabu adalah kasus tertinggi dengan 35 kasus sedangkan 1 kasusnya adalah narkotika jenis ganja. Berdasarkan pengungkapan kasus tindak pidana narkotika pada tahun 2019 diperoleh barang bukti 324 paket shabu-shabu dengan berat kurang lebih 824,31 gram serta 2 paket ganja seberat 2,79 gram.

Berbeda dengan kasus tindak pidana narkotika selama pandemi Covid-19 melanda atau sepanjang tahun 2020 sampai dengan Mei 2021. Pada tahun 2020 tindak pidana narkotika yang terjadi di kota Kendari melonjak hingga hampir $300 \%$ dengan jumlah kasus sebanyak 102 kasus. Kasus tersebut terdiri dari 93 kasus narkotika jenis shabu-shabu, 8 kasus narkotika jenis PCC dan 1 kasus narkotika jenis ganja. Barang bukti yang berhasil diamankan pada pengungkapan kasus tindak pidana narkotika pada tahun 2020 yaitu sebanyak 593 paket shabu dengan berat 1224,92 gram, 498 butir pil PCC seberat 301,58 gram serta 2 paket ganja dengan berat 1,06 gram.

Sementara itu, pada tahun 2021 sampai dengan bulan Mei telah terjadi kasus tindak pidana narkotika sebanyak 64 kasus yang terdiri dari 62 kasus narkotika jenis shabu-shabu dan masing-masing 1 kasus narkotika jenis ganja dan narkotika jenis sinte. Barang bukti shabu yang berhasil diamankan lebih besar dibandingkan pada tahun 2020 yakni 526 paket shabu seberat 1783,17 gram serta 2 batang linting sinte seberat 0.44 gram dan 1 paket ganja seberat 1,34 gram. Baik shabushabu maupun ganja merupakan narkotika golongan I berdasarkan UndangUndang Nomor 35 Tahun 2009. 
Shabu-shabu merupakan serbuk yang memiliki warna putih kristal yang secara ilmiah bernama metamfetamina : (+ )-(S)-N, a -dimetilfenetilamina. Sementara itu, tanaman ganja merupakan tanaman genus cannabis. Hanya saja, banyak disalahgunakan dijadikan bahan campuran untuk lintingan rokok. Shabushabu dan ganja merupakan bagian dari beberapa jenis narkotika yang banyak beredar di masyarakat luas selain morphin, heroin, kokain, opium dan putauw (Junef, 2017).

Sama halnya dengan Pil PCC (paracetamol, caffeine dan carisoprodol) yang merupakan pil yang mengandung carisoprodol yang sering disalahgunakan. Saat ini carisoprodol telah ditetapkan berdasarkan Peraturan Menteri Kesehatan RI Nomor 20 Tahun 2018 tentang Perubahan Penggolongan Narkotika disebutkan bahwa carisoprodol termasuk golongan I narkotika (Habibillah, 2019). Sedangkan sinte merupakan jenis narkotika berbentuk tembakau atau cairan (liquid) rokok elektrik. Sinte atau biasa disebut tembakau gorilla merupakan ramuan herbal yang disemprotkan dengan sejenis bahan kimia sintesis yang hasilnya akan menyerupai efek dari jenis ganja cannabis, apabila dikonsumsi akan mengakibatkan efek berbahaya bagi kesehatan tubuh dan termasuk kedalam golongan I narkotika (Candra \& Yusa, 2019).

Beberapa contoh kasus kejahatan narkotika yang terjadi di kota Kendari diantaranya yang terjadi pada tanggal 12 Desember 2019, Kepolisian Resor Kota Kendari mengamankan 2 (dua) orang pelaku pengedar narkotika di terminal kedatangan bandara haluoleo dengan barang bukti shabu-shabu seberat 212,42 gram. Contoh lain yakni penangkapan pelaku pengedar narkotika pada tanggal 1 Februari 2021 di Kecamatan Wua-wua dengan barang bukti 32 paket narkotika jenis shabu-shabu seberat 1021 gram. Berdasarkan data kasus tindak pidana narkotika yang terjadi di kota Kendari sebagaimana diuraikan di atas, kategori perbuatan melawan hukum yang dilarang dalam Undang-Undang Nomor 35 Tahun 2009 tentang Narkotika yang dilakukan adalah kategori perbuatan memiliki, menyimpan, menguasai, atau menyediakan narkotika golongan I bukan tanaman dan kategori perbuatan menawarkan untuk dijual, menjual, membeli, menerima, menjadi perantara dalam jual beli, menukar, atau menyerahkan narkotika golongan I serta beberapa kategori perbuatan percobaan atau permufakatan jahat untuk melakukan tindak pidana narkotika. Tidak mudah untuk mengklasifikasikan pelaku berdasarkan kategori di atas. Apakah pelaku hanya sebagai penjual, perantara, penerima, pemilik ataupun pemakai. Hal ini disebabkan karena pelaku kadang juga sebagai penjual, perantara atau penyalahguna sekaligus.

Pengungkapan kasus di atas menggambarkan bahwa peredaran gelap dan penyalahgunaan narkotika masih saja tetap terjadi pada kondisi pandemi Covid19. Peningkatan peredaran gelap narkotika terjadi karena permintaan akan narkotika yang tinggi sehingga menyebabkan penawaran pun ikut meningkat. Serangkaian upaya yang dilakukan untuk mencegah peredaran gelap narkotika dirasakan belum maksimal (Adhitya, 2020).

Kasus tindak pidana narkotika yang terjadi di kota Kendari sebagaiman diuraikan di atas, selain dilakukan oleh orang dewasa, juga terdapat beberapa kasus yang dilakukan oleh anak. Selain itu, juga terdapat keterlibatan perempuan dalam tindak pidana narkotika tersebut. Berikut disajikan data kasus tindak pidana narkotika yang terjadi di kota Kendari berdasarkan umur dan jenis kelamin. 
Tabel 2. Jumlah Tersangka Pelaku Tindak Pidana Narkotika di Kota Kendari Berdasarkan Umur dan Jenis Kelamin

\begin{tabular}{cccccc}
\hline Tahun & Jumlah Kasus & \multicolumn{2}{c}{ Batasan Umur Tersangka } & \multicolumn{2}{c}{ Jenis Kelamin } \\
$\leq 18$ Tahun & $>18$ Tahun & Laki-Laki & Perempuan \\
\hline 2019 & 36 & 2 orang & 48 orang & 50 orang & - \\
2020 & 102 & - & 121 orang & 107 orang & 14 orang \\
Mei 2021 & 64 & - & 75 orang & 73 orang & 2 orang \\
\hline
\end{tabular}

Sumber: Data Satuan Reserse Narkoba Polresta Kendari

Berdasarkan data di atas, menunjukan bahwa kasus tindak pidana narkotika yang terjadi di kota Kendari pada masa pandemi Covid-19 terdapat keterlibatan perempuan dalam peredaran gelap ataupun penyalahgunaan narkotika. Sebaliknya, tidak ada satu kasuspun yang melibatkan anak sebagai pelaku tindak pidana narkotika selama masa pandemi Covid-19 ini. Selain jumlah kasus tindak pidana narkotika yang meningkat pada masa pandemi Covid-19, juga terdapat peningkatan pelaku tindak pidana narkotika.

\section{Pembahasan}

Peredaran gelap dan penyalahgunaan narkotika merupakan salah satu dimensi perkembangan kejahatan (crime trend) yang telah lama mendapat perhatian dari Kongres PBB mengenai the prevention of crime and the treatment of offenders. Pada Kongres ke-5 tahun 1975 di Geneva, PBB meminta perhatian salah satunya terhadap kejahatan yang berhubungan dengan alkohol dan penyalahgunaan obat-obatan. Selanjutnya pada Kongres PBB ke-7 tahun 1985 juga dimintakan perhatian terhadap kejahatan yang dipandang membahayakan antara lain yaitu illegal trafficking in drugs (Arief, 2010).

Pola kejahatan bervariasi berdasarkan tempat dan dapat berfluktuasi dalam periode waktu yang singkat. Ini dapat disebabkan oleh gangguan berskala besar seperti Covid-19. Pandemi ini merupakan sumber utama gangguan global. Peredaran gelap dan penyalahgunaan narkotika sebagai salah satu jenis street crime (kejahatan jalanan) merupakan masalah sosial yang masih sulit diatasi. Pada masa pandemi Covid-19 menentukan gambaran perubahan terhadap kejahatan yang terorganisir (salah satunya adalah kejahatan narkotika) untuk mendapatkan keuntungan jangka panjang. Beberapa organisasi kriminal mengambil keuntungan di tengah pandemi Covid-19 dengan memperluas kegiatan peredaran (Tua Situmeang, 2021).

Kejahatan narkotika merupakan masalah yang begitu mengkhawatirkan, tidak hanya kota Kendari, tetapi bangsa Indonesia pada umumnya. Akibat kejahatan narkotika banyak menimbulkan kejahatan-kejahatan lain seperti pencurian, pemerkosaan, pembunuhan dan lainnya. Para sindikat narkotika internasional yang salah satunya dari Malaysia, melakukan berbagai macam cara agar bisa memasukan narkotika secara illegal ke Indonesia. Hal tersebut dikarenakan Indonesia merupakan pasar yang sangat menguntungkan. Penyelundupan narkotika di Indonesia melalui daerah-daerah yang berbatasan langsung dengan negara-negara tetangga (Raja Gukguk \& Jaya, 2019). Terlebih pada masa pandemi Covid-19 saat ini, para sindikat semakin gencar menyelundupkan narkotika dengan memanfaatkan konsentrasi dari negara-negara ataupun daerahdaerah yang tengah mengatasi wabah pandemi ini. 
Di tengah pandemi Covid-19, Direktorat Jenderal Bea dan Cukai Indonesia mencatat adanya perubahan tren modus operandi yang dilakukan para penyelundup narkotika untuk memasukan narkotika tersebut ke Indonesia. Sebelum adanya wabah pandemi Covid-19 modus operandi yang paling sering dilakukan oleh para pelaku penyelundupan narkotika adalah dengan menyembunyikan narkotika di badan ataupun barang bawaan penumpang. Namun, pada masa pandemi Covid-19 ini, modus operandi yang dilakukan untuk menyelundupkan narkotika beralih ke barang kiriman pos ataupun jasa ekspedisi lainnya (Muchtar \& Aziz, 2020).

Tingginya tingkat peredaran dan penyalahgunaan narkotika sebagaimana diuraikan di atas, tidak terlepas dari faktor penyebab penyalahgunaan narkotika itu sendiri. Pertama, faktor individu yang berupa kepribadian yang lemah ataupun dorongan ingin tahu dan ingin coba. Kedua, faktor zat dari narkotika itu sendiri yang dapat mengakibatkan ketergantungan. Ketiga, faktor lingkungan antara lain lingkungan keluarga, lingkungan pergaulan yang dengan mudah memperoleh narkotika. Faktor tersebut di atas ditunjang pula dengan kondisi Indonesia sebagai negara kepulauan yang besar dan memiliki ratusan pelabuhan laut yang membuat Indonesia rawan terhadap penyelundupan narkotika (Krisnawati et al., 2006).

Dalam perspektif kriminologi, terdapat beberapa faktor yang mendorong pelaku melakukan kejahatan yakni diantaranya faktor ekonomi dan faktor lingkungan sosial pelaku. Faktor himpitan ekonomi pada masa pandemi Covid-19 karena adanya PHK ataupun tidak memiliki pekerjaan tetap maupun adanya pembatasan kegiatan masyarakat menyebabkan pelaku nekad mengedarkan narkotika untuk memenuhi kebutuhan hidup secara melawan hukum. Kondisi tersebut ditunjang dengan lingkungan sosial dalam masarakat dimana terdapat tingginya angka peredaran dan penyalahgunaan narkotika (Millah, 2020).

Terkait dengan pelaku peredaran gelap maupun penyalahgunaan narkotika di kota Kendari sebagian besar didominasi oleh pekerja swasta dan wiraswasta. Selain itu para pelaku ada yang berprofesi sebagai Pegawai Negeri Sipil, pegawai honorer, nelayan, petani, supir truk, ojek, kuli bangunan, peternak, ibu rumah tangga, mahasiswa serta beberapa pelaku adalah pengangguran.

Jika dilihat klasifikasi pelaku kejahatan narkotika yang terungkap di kota Kendari, menurut status sosialnya digolongkan ke dalam lower-class criminal, yang merupakan pelaku kejahatan yang tidak memiliki status sosial yang tinggi. Selain itu, jika ditinjau dari segi umur pelaku kejahatan narkotika yang terjadi di kota Kendari, maka sebagian besar diklasifikasikan sebagai adult offenders atau adult criminal, yakni pelaku kejahatan yang dikategorikan sebagai orang dewasa. Walaupun demikian, pada tahun 2019 terdapat pelaku yang masih dikategorikan sebagai anak, yakni seseorang yang belum berusia 18 tahun. Pelaku ini diklasifikasikan sebagai juvenile delinquent atau juvenile offenders (Darmawan, 2016).

Sanksi terhadap penyalahgunaan narkotika dan obat-obatan terlarang lainnya telah diatur dalam Undang-Undang Nomor 35 Tahun 2009 tentang Narkotika, hal ini dapat digolongkan sebagai berikut:

a. Sebagai penyalahguna narkotika golongan I dikenakan ketentuan pidana berdasarkan Pasal 127 Undang-Undang Nomor 35 Tahun 2009 tentang Narkotika, dengan pidana penjara paling lama 4 tahun. 
b. Sebagai produsen tunduk pada ketentuan pidana berdasarkan Pasal 113 Undang-Undang Nomor 35 Tahun 2009 dengan ancaman hukuman maksimal 20 tahun atau seumur hidup atau pidana mati dan denda.

c. Sebagai pengedar, perantara atau penjual juga diancam dengan pidana maksimal 20 tahun atau seumur hidup atau pidana mati dan denda (Sulaiman \& Lampatta, 2020).

Pelaku-pelaku kejahatan narkotika yang berhasil diungkap oleh kepolisian pada dasarnya merupakan bagian kecil dari pelaku-pelaku kejahatan narkotika yang ada. Diluar sana masih banyak terdapat pelaku kejahatan narkotika yang jumlahnya tidak sebanding dengan pelaku kejahatan narkotika yang telah diproses hukum.

\section{Kesimpulan}

Berdasarkan hasil dan pembahasan dapat disimpulkan bahwa (1) peredaran gelap maupun penyalahgunaan narkotika di kota Kendari mengalami peningkatan kasus yang sangat signifikan selama pandemi Covid-19 yakni sepanjang tahun 2020 sampai bulan Mei 2021; (2) Selain peningkatan kasus, pengungkapan kasus tindak pidana narkotika selama pandemi Covid-19 juga terjadi peningkatan pelaku serta barang bukti yang diamankan; (3) kasus peredaran atau penyalahgunaannya narkotika yang tinggi adalah narkotika jenis shabu-shabu; (4) terdapat keterlibatan perempuan dalam kejahatan narkotika selama pandemi Covid-19 di kota Kendari. Untuk melakukan pencegahan dan penanggulangan terhadap peredaran gelap dan penyalahgunaan narkotika khususnya pada masa pandemi Covid-19 ini, kiranya harus dilakukan penelitian yang lebih mendalam terkait faktor-faktor yang menyebabkan terjadinya peningkatan kasus kejahatan narkotika di kota Kendari.

\section{Daftar Pustaka}

Adhitya, B. (2020). Analisis Keterlibatan Wanita dalam Tindak Pidana Peredaran Narkotika pada Masa Pandemi Covid-19. Sol Justicia, 3(2), 249-256. Retrieved from http://ojs.ukb.ac.id/index.php/sj/article/view/198

Arief, B. N. (2010). Bunga Rampai Kebijakan Hukum Pidana (Perkembangan Penyusunan Konsep KUHP Baru). Jakarta: Kencana.

BPS Provinsi Sulawesi Tenggara. (2021). Provinsi Sulawesi Tenggara Dalam Angka 2021. (BPS Provinsi Sulawesi Tenggara, Ed.). Kendari: BPS Provinsi Sulawesi Tenggara. Retrieved from https://sultra.bps.go.id/publication/2021/02/26/01 cfcc4218d088f6a77f63cf/prov insi-sulawesi-tenggara-dalam-angka-2021.html

Candra, K. N. S. D., \& Yusa, I. G. (2019). Tindak Pidana Penyalahgunaan Tembakau Gorilla Di Tinjau Dari Undang-Undang Nomor 35 Tahun 2009 Tentang Narkotika. E-Journal IImu Hukum Kertha Wicara Fakultas Hukum Universitas Udayana, 8(4), 1-15. Retrieved from https://ojs.unud.ac.id/index.php/kerthawicara/article/view/50851/30122

Darmawan, M. K. (2016). Teori Kriminologi. Tangerang Selatan: Universitas Terbuka.

Habibillah, A. S. (2019). Reformulasi Sanksi Pidana Terhadap Pengguna Pengguna PIL PCC (Paracetamol, Cafeine dan Carisoprodol) dalam Hukum 
Pidana Indonesia. JOM Fakultas Hukum, VI(2), 1-15. Retrieved from https://jom.unri.ac.id/index.php/JOMFHUKUM/article/view/26467/25587

Hiariej, E. O. S. (2009). Pengantar Hukum Pidana Internasional. Jakarta: Erlangga. Irwansyah. (2020). Penelitian Hukum, Pilihan Metode \& Praktik Penulisan Artikel. Yogyakarta: Mirra Buana Media.

Junef, M. (2017). Forum Makumjakpol-BNN-MENKES-MENSOS Dalam Penanganan Tindak Pidana Narkotika. JIKH: Jurnal Ilmiah Kebijakan Hukum, 11(3), 305-336. Retrieved from https://ejournal.balitbangham.go.id/index.php/kebijakan/article/view/302/pdf

Krisnawati, D., Hiariej, E. O. ., Gunarto, M. P., Riyatno, S., \& Supriyadi. (2006). Bunga Rampai Hukum Pidana Khusus. Jakarta: Pena Pundi Aksara.

Maricar, F., \& Nurfani. (2021). Anomali Bahasa dan Budaya di Era Pandemi Covid19. Sang Pencerah Jurnal IImiah Universitas Muhammadiyah Buton, 7(1), 120-132. https://doi.org/https://doi.org/10.35326/pencerah.v7i1.936

Millah, I. A. (2020). Penanggulangan Kejahatan Di Masa Pandemi Covid-19 (Dalam Perspektif Kriminologi Dan Viktimologi). Jurnal Komunikasi Hukum (JKH) Universitas Pendidikan Ganesha, 6(2), 497-513.

Muchtar, M., \& Aziz, R. A. (2020). Tantangan dan Strategi Pengawasan Narkotika, Psikotropika, dan Prekursor di Masa Pandemi Covid-19. Jurnal Perspektif Bea Dan Cukai, 4(2), 111-122. Retrieved from http://jurnal.pknstan.ac.id/index.php/PBC/article/view/964

Muladi, \& Arief, B. N. (2005). Teori-Teori dan Kebijakan Pidana. Bandung: PT. Alumni.

Raja Gukguk, R. G., \& Jaya, N. S. P. (2019). Tindak Pidana Narkotika Sebagai Transnasional Organized Crime. Jurnal Pembangunan Hukum Indonesia, 1(3), 337-351. https://doi.org/10.14710/jphi.v1i3.337-351

Reksodiputro, M. (2020). Sistem Peradilan Pidana. Depok: PT Raja Grafindo Persada.

Santoso, T., \& Zulfa, E. A. (2011). Kriminologi. Jakarta: PT Raja Grafindo Persada.

Sulaiman, H., \& Lampatta, M. R. (2020). Law enforcement and eradication of criminal actions of narcotics in Pohuwato district area. Jurnal Hukum Volkgeist, 5(1), 1-13.

Sunggono, B. (2011). Metodologi Penelitian Hukum. Jakarta: PT Raja Grafindo Persada.

Triana, A. A., \& Fauzi, A. M. (2020). Dampak Pandemi Corona Virus Diserse 19 Terhadap Meningkatnya Kriminalitas Pencurian Sepeda Motor Di Surabaya. Syiah Kuala Law Journal, 4(3), 302-309. https://doi.org/10.24815/sklj.v4i3.18742

Tua Situmeang, S. M. (2021, April). Fenomena Kejahatan di Masa Pandemi Covid19: Perspektif Kriminologi. Majalah IImiah UNIKOM, 19(1), 35-43. Retrieved from https://ojs.unikom.ac.id/index.php/jurnal-unikom/article/view/5067 